原 著

めまい患者の大脳 MRI 皮質下白質変化の検討

水田啓介・安藤 健一, 久世 文也・村井 道典

横田 陽一 - 山田 南星・青木 光広 $\cdot$ 伊藤 八次

\title{
Deep White Matter Lesions on MRI in Elderly Patients with Dizziness
}

\author{
Keisuke Mizuta, Kenichi Ando, Bunya Kuze, Michinori Murai \\ Yoichi Yokota, Nansei Yamada, Mitsuhiro Aoki, Yatsuji Ito \\ Department Otolaryngology, Gifu University Graduate School of Medicine
}

High intensity signals on T2-weighted magnetic resonance imaging (MRI) of cerebral white matter are common in aged people. A recent study suggests that these lesions increase with risk factors for stroke from arteriolosclerosis. Some investigators have identified a relationship between these white matter lesions and dementia or motor deficits. The clinical significance of these white matter lesions remains unclear. To investigate the relationship between these white matter lesions identified on magnetic resonance imaging and dizziness in elderly patients, we evaluated findings on brain MRI of patients with dizziness $(n=108)$ and patients without dizziness $(n=28)$ aged over 60 years old. Deep white matter hyperintense signals (DWMH) and periventricular hyperintensity (PVH) were graded using a qualitative rating scale (Fazekas et al.). Patients with dizziness, especially originating in the central nervous system, showed significantly more severe white matter lesions (grade 2-3). We suggest that older patients with severe white matter high intensity signals experience dizziness due to vascular insufficiency from arteriolosclerosis.

Key words: MRI, white matter high intensity lesion, aged patients, dizziness

\section{はじめに}

近年，高齢者めまい患者が増加している1”。高 龄者のめまい患者では脳循環不全など中枢性めま いが青壮年めまい患者より多いと言われている。 従って高齢者めまい患者では脳 MRI を撮影する 機会が多い。高㱓者めまい患者の脳 MRI では脳 血管障害や脳腫瘍を診断する目的で撮影されてい るため, 明らかなこれらの病変を認めないときた は異常なしと判定される。高龄者の脳 MRI では

岐阜大学大学院医学系研究科耳鼻咽喉科学分野
大脳の皮質下白質や脳室周囲湾高信号变化を認め ることが多い。しかし，この大脳深部白質高信号 域 (deep white matter hyperintense signals, DWMH）や脳室周团高信号領域（periventricular hyperintensity, PVH）は加龄変化として知られて いるため231)に，高龄者に認められた場合には特 に評価されていないことが多い。一方，DWMH やPVH は高度変化例では脳動脈硬化との関連が 報告されている4)5\%

今回我々は，高齢者の脳 MRIでみら礼る DWMH やPVH とめまい，特に中枢性めまいと 
表 1 対象一覧

\begin{tabular}{lc|ccc}
\hline & & 60 歳代 & 70 歳代 & 80 藏代 \\
\hline 非めまい例 & 28 例 & 14 例 & 13 例 & 1 例 \\
\hline めまい例 & 108 例 & 55 例 & 42 例 & 11 例 \\
\hline 内耳性めまい例 & 52 例 & 35 例 & 12 例 & 5 例 \\
中枢性めまい例 & 33 例 & 10 例 & 19 例 & 4 例 \\
その他のめまい例 & 23 例 & 10 例 & 11 例 & 2 例 \\
\hline
\end{tabular}

の関連を娭討した。

\section{対象と方法}

対象は平成13年 1 月から 15 年 6 月までに岐阜大 学医学部附属病院耳鼻咽喉科を受診し，当院で脳 MRI を撮影し，明らかな脳腫瘍や脳血管障害を 認めなかった60歳以上の136例である（表 1 ）。め まい例は108例で60歳代は55例，70歳代は42例， 80歳代11例，非めまい例は28例で60歳代は14例， 70 歳代は13例，80歳代は1例であった。非めまい 例以顔面神経麻疩例，感音難聴例，耳鳴例，三叉 神経障害例，原因不明の頭痛例などである。

めまいの障害部位診断は病歴, 神経学的所見, 眼振所見，温度眼振検査やVEMPなどで行い， 内耳性めまい, 中枢性め交汇診断し，前記で診 断不能な例は原因不明とした。

内耳性め主い例は52例で，60歳代は35例，70歳 代は12例，80歳代は 5 例であった。中枢性めまい 例は33例で，60歳代は10例，70歳代は19例，80歳 代は 4 例であった。原因不明めまい例は24例で あった。

脳 MRI の評価は $\mathrm{T} 2$ 強調画像 $(\mathrm{Tr}=2000 \mathrm{msec}$, $\mathrm{Te}=100 \mathrm{msec}$ ）で行った。脳 MRI の大脳皮質下 白質変化は Fazekas ら ${ }^{6)}$ の評価法を用いて行っ た。すなわち, DWMH は認めないものを grade 0, 点状の高信号を grade 1, 連続する高信号を grade 2, 大きな高信号を grade 3 とし，PVH は認めな いものを grade 0 , 線状の高信号を grade 1, 暈状 の高信号を grade 2, 不規則な厚い高信号を grade 3 とした（図 1)。

高齿者の脳 MRI でみられる大脳皮質下白質変 化とめまいとの関連を検討寸る目的で，めまい例 と非めまい例の脳 MRI の DWMH と PVH の程 度を比較検討した。特に中枢性めまいへの脳 MRI の白質変化の関与を検討する目的で, 内耳
性めまい例と中枢性めまい例の脳 MRI の DWMH とPVHの程度を比較検討した。脳 MRIの $\mathrm{DWMH}$ や PVH 所見の程度は加齢に伴って高度 になることが知られており，年齢を考慮するため に，10歳毎に検討した。

2 群間の差の検定には Mann-Whitney 検定を用 いた。脳 MRI の白質変化所見の Grade 2 以上を 高度所見之捉え，めまいと脳 MRI 高度所見，中 枢性めまいと脑 MRI 高度所見の関連性の検定に

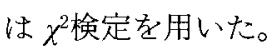

80 歳代は例数が少ないため, 今回 $60 ・ 70$ 歳代の みを評価した。

\section{結 果}

1. あまいと脸 MRI 皮質下白質変化

60 歳以上のめまい例108例と非めまい例28例の 脳 MRI の DWMH, PVH の程度を比較した（表 2)。60歳代ではめまい例と非めまい例では 2 群 間に有意差は認めなかったが，DWMH，PVH と もにめ屯い例では非めまい例に比べて Grade 2 以 上の例が有意に多かった $(P<0.05)$ 。70歳代では $\mathrm{PVH}$ ではめまい例と非めまい例の 2 群間に有意 差を認めた $(P<0.05)$ 。 DWMH， PVH ともにめ まい例では非めまいに比べて Grade 2 以上の例が 有意に多かった $(P<0.05)$ 。

すなわち，60歳・70歳代のめまい患者では非め まい患者に比べて脳 MRI での grade 2 以上の高 度の皮質下白質变化を認めた。

2. ぬむ障害部位と脑 MRI 皮質下白質变化

60歳以上の内耳性めまい例52例之中枢性めまい 例33例の脳 MRI の DWMH, PVH の程度を比較 した（表 3）。60歳代では内耳性めまい例と中枢 性めまい例では 2 群間に有意差は認めなかった が，DWMH，PVH ともに中枢性めむい例では内 耳性めまい例に比べ Grade 2 以上の例が有意に多 


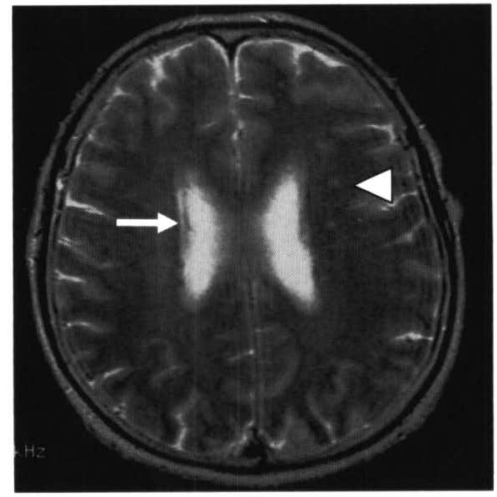

(a)

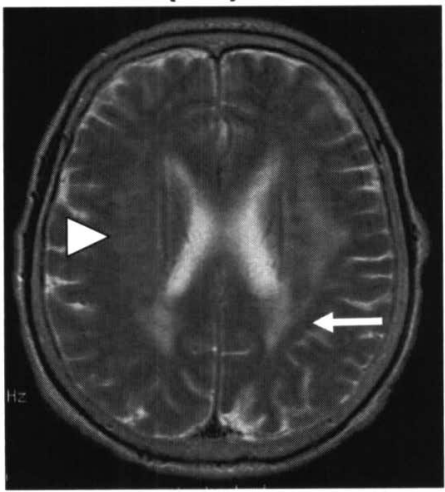

(d)

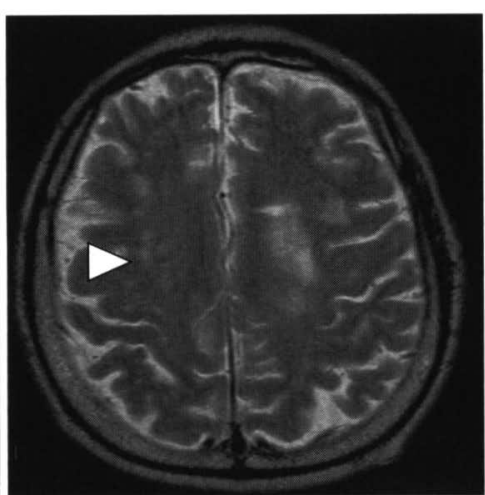

(b)

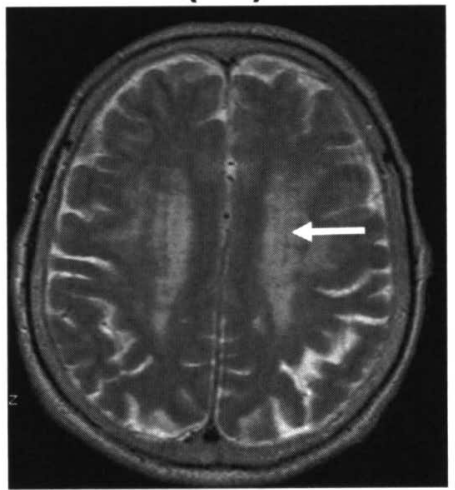

(e)

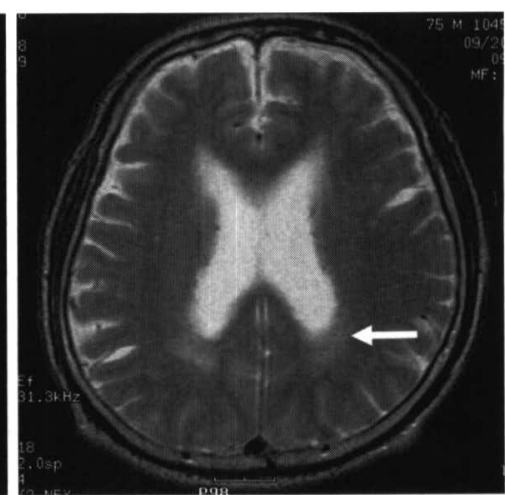

(c)

図 1 脳 MRI の大脳皮質下白質変化評価法

脳 MRI の T2 強調画像を用いて Fazekas $5^{4)}$ の評価に従って DWMH, PVH を grade 0 から grade 3 まで の 4 段階に分類した。

（a）の $\triangle$ は点状の DWMH を指し示しており，DWMH grade 1 と判定する。 $\rightarrow$ は線状の PVHを指し， PVH grade 1 と判定する。(b) の $\triangle$ は連続する DWMH を指し示しており, DWMH grade 2 と判定する。(c)

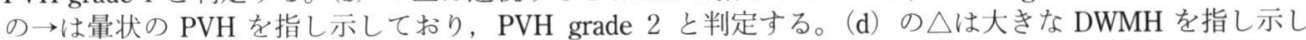
ており, DWMH grade 3 と判定する。(d) の PVH grade 3 と判定する。

表 2 めまいの有無と脳 MRI 皮質下白質変化

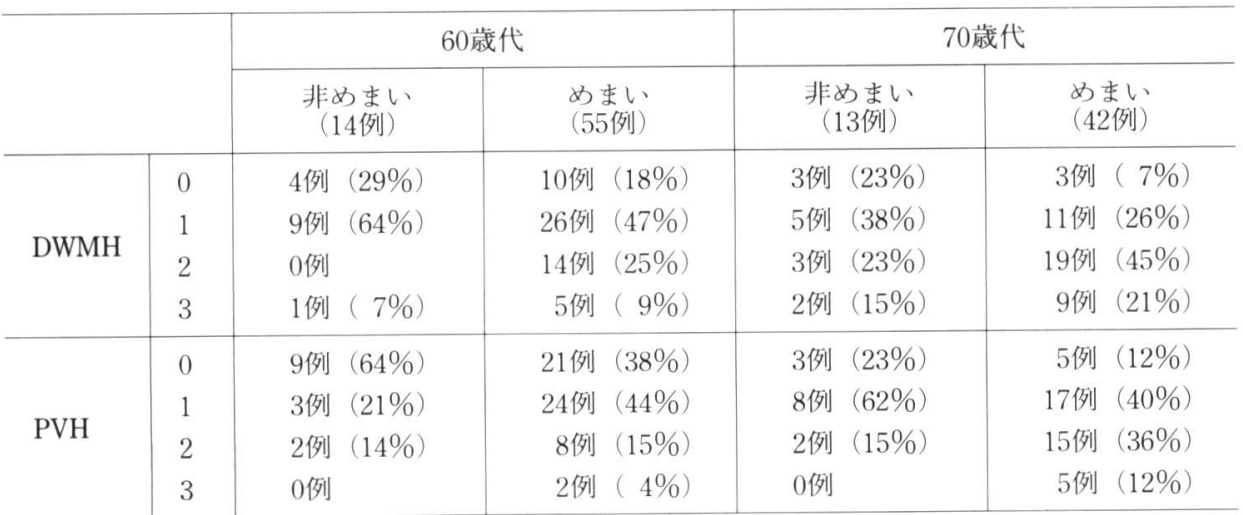


表 3 めいいの障害部位と脳 MRI 皮質下白質变化

\begin{tabular}{|c|c|c|c|c|c|}
\hline & & \multicolumn{2}{|c|}{ 60歳代 } & \multicolumn{2}{|c|}{ 70歳代 } \\
\hline & & $\begin{array}{l}\text { 内耳性 } \\
(35 \text { 例 })\end{array}$ & $\begin{array}{l}\text { 中枢性 } \\
\text { (10例) }\end{array}$ & $\begin{array}{l}\text { 内耳性 } \\
(12 \text { 例) }\end{array}$ & $\begin{array}{l}\text { 中枢性 } \\
\text { (19例) }\end{array}$ \\
\hline \multirow{4}{*}{ DWMH } & 0 & 9例 $(26 \%)$ & 1例 $(10 \%)$ & 2例 $(17 \%)$ & 1例 ( $5 \%)$ \\
\hline & 1 & 17例 $(49 \%)$ & 2例 $(20 \%)$ & 5 例 $(42 \%)$ & 4例 $\quad(26 \%)$ \\
\hline & 2 & 8例 $(23 \%)$ & 6 例 $(60 \%)$ & 3例 $(25 \%)$ & 9例 (47\%) \\
\hline & 3 & 1例 $(3 \%)$ & 1例 $(10 \%)$ & 2 例（17\%） & 5 例 (26\%) \\
\hline \multirow{4}{*}{ PVH } & 0 & 13例 $(37 \%)$ & 1例 $(10 \%)$ & 3例 $(25 \%)$ & 1 例 $(5 \%)$ \\
\hline & 1 & 19例 $(54 \%)$ & 5 例 $(50 \%)$ & 7 例 $(58 \%)$ & 5 例 $(26 \%)$ \\
\hline & 2 & 3例 (9\%) & 4 例 $(40 \%)$ & 1 例 $(8 \%)$ & 10 例 $(53 \%)$ \\
\hline & 3 & O例 & 0例 & 1例 $(8 \%)$ & 3 例 $(16 \%)$ \\
\hline
\end{tabular}

かった（P<0.05）。70歳代では内耳性めまい例と 中枢性めまい例では 2 群間に有意差は認めなかっ たが，DWMHでは中枢性めまい例では内耳性め 屯い例に比べ Grade 2 以上の例が多い傾向があっ た $(P<0.1)$ 。PVH では中枢性めまい例では内耳 性めまい例に比べ Grade 2 以上が有意に多かった $(P<0.05)$ 。

すなわち，60歳代の中枢性めまい患者では内耳 性めむい患者に比べて脳 MRIでの grade 2 以上 の高度の皮質下白質変化をもち，“また70歳代でも その傾向があることが示された。

\section{考察}

高齢者に脳 MRI を撮影したときに大脳深部白 質に点状高信号域がみられるのは正常高齢者でる 一般に観察されるといわれて蚛方，大脳皮質下の 点状高信号域所見は加㱓変化による所見であると 認識されている。しかし，亏つ病患者やAlzheimer 病患者では DWMH やPVH などの大脳 皮質下白質变化の程度之疾患の重症度が相関する という報告がされるようになった7つ 10)。

大脳皮質下白質変化は $\mathrm{T} 2$ 強調画像で高信号 に, T1 強調画像ではほぼ等信号に認められ，梗 塞とは異なる MRI 画像を示す。この病理につい て，患者の剖検から小梗塞やサブクリニカルな虚 血により blood brain barrier が破綻し, astrocyte が活性化されとともにグリオーシスが形成されて いる報告があり，これらの変化ふ脳の小血管の動 脈硬化性変化によると推察されている1112)。

めまいや平衡障害と大脳皮質下白質变化との関 連に関しては, めまい患者では正常人より
DWMH が有意に多い13)，バランス障害や歩行障 害のある高龄者では脳 MRI で高度な PVH 所見 認める ${ }^{14\rangle}$ ，正常高齢者では DWMH 所見の程度 と歩行・バランス機能と相関を認める15) という 報告がある。

今回我々の検討で, めまいの訴えのない高齢者 患者よりめまいを訴光る患者では，Grade 2 以上 (Fazekas らの評価分類) の高度な DWMHと PVH 所見をもつ例が有意に多いことが示された。 また，中枢性めまい患者では内耳性めまい患者に 比べ高度な DWMH と PVH 所見をもつ例が有意 に多いことが示された。このことから，脳 MRI の DWMH と PVH などの大脳深部白質の高度変 化は単なる加龄変化ではなく異常所見と評価して よいと考兄られる。高齢めまい患者で高度所見を もつ例は加齢変化に伴 5 MRI 所見に加兄て脳動 脈硬化に伴う病的所見が加わったものと推察され る。高齢めまい患者悱めまい患者に比べ高度な 大脳皮質下白質変化をもつこと中，大脳皮質下白 質変化の高度所見と相関する脳動脈硬化による障 害が強いためと考えている。この脳動脈硬化によ り障害は内耳含まれる可能性があり，中枢障害 も潜在的にある可能性がある。特に中枢性めまい 例で高度な大脳皮質下白質变化を認める理由は, 高齢者めまい患者では脳動脈硬化による中枢（大 脳のみならず，小脳・脳幹を含め）の障害による めまいが多いことによると推察される。

高齢者の脳 MRI で高度な大脳皮質下白質変化 がみられても脳動脈硬化を示唆する $1 つ の$ 所見が 示されているにすぎないため，その所見だけで 
は，中枢異常を疑わせるわけではない。めまいの 診断は病歴や神経・神経耳科学的所見・平衡機能 検査所見からされるが，脳 MRI の大脳皮質下白 質変化の程度も中枢性めまいを䛦断する際に重要 な参考所見として有用であると思われる。

\section{結 語}

60 歳以上の136例（めまい例108例，非めまい例 28例）の脳 MRI の大脳皮質下白質変化 （DWMH，PVH）を検討した。めまい例では非め まい例より，特に中枢性めまい例では内耳性めま い例より, DWMH P PVH の高度な所見（Fazekas らの評価で Grade 2 以上）をもつことが多いこと が示された。

本稿の要旨は, 第61回日本めまい平衡医学会 (平成14年10月，富山）でロ演した。

\section{文献}

1) 大和田聡子, 石田 孝, 高野澤美奈子, 他 : 当科に招ける高齢者めまいについての統計的 検討. Equilibrium Res 64: 203-210, 2005

2) Ylikoski A, Erkinjuntti T, Raininko R, et al: White mattter hyperintensities on MRI in the neurologically nondiseased elderly. Analysis of cohorts of consecutive subjects aged 55 to 85 years living at home. Stroke 26: 1171-1177, 1995

3 ) George $\mathrm{AE}$, de Leon MJ, Kalnin A, et al: Leukoencephalopathy in normal and pathologic aging: 2. MRI of brain lucencies. AJNR Am J Neuroradiol 7: 567-570, 1986

4) van Swieten JC, van den Hout JH, van Ketel $\mathrm{BA}$, et al: Periventricular lesions in the white matter on magnetic resonance imaging in the elderly. A morphometric correlation with arteriolosclerosis and dilated perivascular spaces. Brain 114: 761-774, 1991

5) Jeerakathil T, Wolf PA, Beiser A, et al: Stroke risk profile predicts white matter hyperintensity volume: the Framingham Study. Stroke 35: 1857-1861, 2004

6) Fazekas F, Chawluk JB, Alavi A, et al: MR signal abnormalities at $1.5 \mathrm{~T}$ in Alzheimer's dementia and normal aging. AJR Am J Roentqenol 149: 351-356, 1987
7 ) Kramer-Ginsberg E, Greenwald BS, Krishnan KR, et al: Neuropsychological functioning and MRI signal hyperintensities in geriatric depression. Am J Psychiatry 156: 438-444, 1999

8) Fazekas F, Kapeller P, Schmidt R, et al: The relation of cerebral magnetic resonance signal hyperintensities to Alzheimer's disease. J Neuro Sci 142: 121-125, 1996

9) Lin HF, Kuo YT, Chiang IC, et al: Structural abnormality on brain magnetic resonance imaging in late-onset major depressive disorder. Kaohsiung J Med Sci 21: 405-411, 2005

10) Garde E, Lykke Mortensen E, Rostrup E, et al: Decline in intelligence is associated with progression in white matter hyperintensity volume. J Neurol Neurosurg Psychiatry 76: 1289-1291, 2005

11) Baloh RW, Vinters HV: White matter lesions and disequilibrium in older people. II. Clinicopathologic correlation. Arch Neurol 52: 975981, 1995

12) Takao M, Koto A, Tanahashi N, et al: Pathologic findings of silent hyperintense white matter lesions on MRI. J Neurol Sci 167: 127-131, 1999

13) Fujishima M, Yao H, Terashi A, et al: Deep white matter lesions on MRI, and not silent brain infarcts are related to headache and dizziness of non-specific cause in non-stroke Japanese subjects. Intern Med 39: 727-731, 2000

14) Baloh RW, Yue $Q$, Socotch TM, et al: White matter lesions and disequilibrium in older people. I. Case-control comparison. Arch Neurol 52: 970-974, 1995

15) Baloh RW, Ying SH, Jacobson KM: A longitudinal study of gait and balance dysfunction in normal older people. Arch Neurol 60: 835-839, 2003

原稿到着 : 平成17年10月 24 日

別刷請求先: 水田啓介

テ501-1194 岐帛市柳戸1-1

岐阜大学大学院医学系研究科耳鼻咽喉科学分野 